\title{
IMPLICATIONS OF INDONESIA'S NEW FOREIGN INVESTMENT POLICY FOR ECONOMIC DEVELOPMENT
}

\author{
Hong Lan Oei*
}

\section{A Major Reversal in Foreign Investment Policy}

The widely publicized and by now well known fundamental and drastic changes in political outlook and economic policy since the abortive coup d'etat of october 1965 have, in some cases slowly, and in others, more rapidly, pervaded all sectors of economic and political life in Indonesia. It should therefore come as no surprise that the attitude towards foreign investment has also undergone a thorough-going change. Nevertheless, the rapidity and the extent of the reversal in foreign investment policy have perplexed even the most seasoned observers of Indonesian affairs. It should be noted that the new foreign investment law, Law No. I of January 1, 1967, was promulgated at a time when the so-called "dualism" in state leadership still existed, with sukarno still formally president but with General Suharto already holding full executive powers, and when, in the words of the Chairman of the Indonesian Technical Committee on Capital Investment, "the effective Government under suharto was trying to reverse major national policies against the desperate opposition of President Sukarno. . . " l

Under these circumstances, it is understandable that the new law was in many respects still vague and even ambiguous. Subsequent developments, however, have shown the seriousness of the intentions of the government in implementing it through additional laws and regulations.

The purpose of this paper is, first of all, to follow developments in government policy regarding foreign investment in the light of the pronounced objective of promoting economic development.

* The author is a member of the United Nations ECAFE Secretariat in Bangkok. However, the views and opinions expressed in the paper, which was prepared by him in his personal capacity, are not necessarily those of ECAFE.

1. Professor M. Sadii, in a presentation before the meeting of the Pacific Indonesia Business Association, as quoted in: Stanford Research International, Report No. 3, 1967, The Djakarta Report, Menlo Park, California, 1967, p. 9. For an official English translation of Law No. 1/1967, See: Indonesia, Department of Information, Investment: The New Procedures of Foreign Capital Investment (Djakarta, 1968). 
Secondly, the paper will attempt to assess the implications of the new policy for future economic development. While the new attitude towards foreign investment should be welcomed, in view of Indonesia's shortage of capital and of technical and managerial skills, and in view of persistent balance of payments difficulties, it remains to be seen whether a too liberal attitude towards the inflow of such capital will be in line with general economic development policy in Indonesia. Logging concessions without regard to conservation policies, for instance, may lead Indonesia in the future to imitate the unfortunate example of excessive forest denudation set by the Philippines. The same can be said of fishery concessions. In the field of mining and estate agriculture, concessions without stipulating the desirability of local processing of the commodities produced and exported may lead to a perpetuation of Indonesia's position as a supplier of raw materials at a time when world prices for raw materials are generally believed to be undergoing a long-term downward trend. As pointed out by Professor Sadli, ". . candidates for investment in Indonesia should realize that they will work and live in a country that has been emancipated from a colonial past and is striving to build up a national economy that must not be made an adjunct of westem business empires. Economic nationalism is an important feature in our revolution and is here to stay." 2

On the other hand, a continued moratorium on mineral exploration and neglect of fishery and forest resources will lead Indonesia nowhere, socialism and anticolonialism notwithstanding.

In view of these problems, a general review of actual developments in the implementation of foreign investment policy will be given, including an enumeration of the problems encountered by foreign investors and the likelihood of the actual inflow of foreign capital as distinct from the maximal amount granted by the permits. It should be noted that both of Indonesia's closest neighbors, the Philippines and Malaysia, which have similar economies to Indonesia's but which have a longer record of favorable attitudes towards foreign investment, have recently promulgated new investment incentive acts and are actively engaging in foreign investment promotion. ${ }^{3}$

Indonesia, on the other hand, has the advantage of having been virtually closed to new foreign investment projects for

2. Djakarta Report, p. 9 .

3. Malaysia, The Investment Incentives Act, 1968, Kuala Lumpur, February 29, 1968. Philippines, Investment Incentive Act, 1967, Republic Act No. 5186, Manila, September 16, 1967. Also Basic Rules and Regulations, issued by the newly established Board of Investment. 
over twenty years. Indonesia's 115 million people offer a huge potential market for many import substituting industries; its untapped forest resources and unexplored but potentially rich mineral wealth may form the basis of many new export industries.

\section{Attitude Towards Foreign Investment: 1949-1966}

The attitude towards foreign investment during the period 1949 to 1966 was never consistent. A state of persistent uncertainty prevailed as the continuing conflict between the recognized need for additional capital for development purposes to supplement domestic resources and economic nationalism and resentments of foreign dominance of the economy inherited from the colonial era remained unresolved.

The "liberal" period between December 1949 and August 1959 was a period in which frequent changes occurred in government policy due to a rapid turnover of coalition cabinets. During this period there were no less than eight such cabinets, some of them remaining in power for only a few months.

Politically, this period could be further subdivided into two: the period of the first four cabinets, from December 1949 to July 1953, when the government attitude was generally believed to be more "pro-western," and the period of the next four cabinets, when, in the words of John Sutter, the outlook was dominated by "less tolerant ultra-nationalist and socialist politicians."

The economic equivalent of this political conflict, while not always neatly coinciding with the political subperiods, was also felt throughout the period, causing many issues, especially with regard to foreign investment policy, to remain unresolved.

Thus in 1951, a resolution was passed in parliament in which a State Commission on Mining Affairs was appointed to report on the desirable operation of all mining rights in Indonesia. Pending the report of the Commission, the government was asked to postpone the granting of all concessions

4. John Sutter, Indonesianisasi, Politics in a Changing Economy, 1940-55 (Ithaca: Cornell University, 1959). Also: Herbert Feith, "Dynamics of Guided Democracy," in Ruth McVey (ed.), Indonesia (New Haven: HRAF, 1963), pp. 3I4ff. For a comprehensive discussion of the implications for economic policy see Bruce Glassburner, "Economic Policy Making in Indonesia, 1950-57," Economic Development and Cultural Change, X, No. 2, Part I (January 1962). 
and exploitation permits and the extension of expired permits. As it turned out, the Commission took eight years to deliberate and report and only in 1960 were laws regulating petroleum and other mineral explorations passed. ${ }^{5}$ The adverse effects of the prolonged moratorium between 1939 and 1963 on mineral and petroleum production and exports can only be roughly estimated.

Another example of the detrimental effect of the continuous conflict between opposing views can be seen in the repeated postponement of the enactment of the first foreign investment bill originally drafted in 1953. The draft bill was ultimately approved by the cabinet in June 1956, but it took another two years before it was passed by Parliament (with a few amendments), only to be repealed by President Sukarno in mid-1959.6

The first foreign investment law was very general in nature. It recognized the needs for foreign capital and granted assurances of non-nationalization for periods of 20 or 30 years depending on the nature of the enterprise. The provisions for transfer of profits and for lightening the burden of taxation were kept vague while nationwide transportation services and other fields of endeavor remained closed to foreign enterprise. The law had little consequence in attracting foreign investment as the general political climate became increasingly hostile towards foreign capital.

The period of "Guided Democracy" and "Guided Economy'," for mally launched by Sukarno in July 1959, was marked by relatively more stability in the government. Parliament was reorganized and reduced to a "rubber stamp" body. The cabinet was led by the president himself and was no longer responsible to parliament. In the field of foreign investment, more radical attitudes were evinced but the basic dilemma continued to plague government policy. This was demonstrated by the eight-year plan for 1961-69 adopted in 1960. Muhammad Yamin, Chairman of the National Planning Council, argued against contracting foreign loans on the ground that debt service repayment was getting burdensome. He opted in favor of financing the plan through the "development of natural resources" and implicitly, in favor of foreign investment rather than loans. But since the expropriation of all Dutch interests in December 1957, there was little predisposition to accept a policy in favor of direct foreign investment. Therefore the government cautiously developed a new plan of cooperation with foreign enterprises which later became known as production-sharing contracts.

5. Law No. 37/Prp. 1960 on Mining and Law No. 44/Prp. 1960 on Oil and Natural Gas.

6. English version of the Foreign Investment Law in AmericanIndonesian Chamber of Commerce, Information Bulletin, No. 551, October 23,1958 . 
The petroleum and gas exploration law of 1960 stipulated that all mineral oil and gas constituted national wealth and that such mining could only be undertaken by the state. If necessary, the government could appoint another party as a contractor on the basis of production-sharing. On August 3 , 1962, President Sukarno issued an official statement on production-sharing, defining such contracts as foreign credits provided for a specific project, the credit to be repaid within a stipulated time with an agreed percentage of the product of the project. ${ }^{7}$

This compromise concept, which finally brought together the opposing views on foreign investment, came under attack from the Communist Party which became increasingly powerful after 1959. The late D. N. Aidit, chairman of the party, stated that all forms of foreign investment constituted imperialism and that new forms of such investment, whether in the form of joint ventures, production-sharing, or contractor deals were just subtle forms of continuing domination by foreign economic enterprise. He likened the new forms of foreign investment to sharecropping practices in agriculture. ${ }^{8}$

Under these circumstances, the new production-sharing policy was not able to attract really sizeable amounts of foreign capital. Expropriation of foreign property came in two waves. The first, as noted earlier, was directed against all Dutch enterprises in December 1957, in response to the defeat of a pro-Indonesian motion in the U.N. General Assembly on the problem of West Irian. The second wave came in 1963-65 against British, American, Belgian and Malaysian interests in conformity with Indonesia's confrontation policy against Malaysia.

Thus, two political issues, the West Irian issue and the Malaysia issue, resulted in the virtual elimination of foreign direct investment in Indonesia except in the petroleum industry and in a few production-sharing contracts in other fields. Agitation continued against these last vestiges of foreign capital up to the time of the coup d'etat in October 1965.

The New Foreign Investment Policy

The significance of the new investment policy lies not merely in the passage of a new foreign investment law, but also,

7. Statement on Production Sharing Arrangements issued by the President in August 1962.

8. D. N. Aidit, Sosialisme Indonesia dan Sjarat-Sjarat Pelaksanaannja (Djakarta: "Aliarcham," 1962), Pp. 97-98. 
and perhaps more importantly, in the follow-up measures and the actual implementation of the law as well as in the general economic climate of the country.

During 1967 and 1968, Investment Guarantees Treaties were concluded between the government of Indonesia and the governments of the United States, Denmark, the Netherlands and West Germany. Since the signing of the treaty with the United States, 55 American companies have submitted applications to A.I.D. for possible investments of over $\$ 600$ million, of which $\$ 400$ million is in the field of mining, including petroleum. Of course, the $\$ 600$ million should only be considered potential investment. ${ }^{9}$

In February 1968, Indonesia decided to enter into the Convention on the settlement of International Disputes between States and Nationals of other States. This convention was sponsored by the International Bank for Reconstruction and Development and opened for signature by member governments on March 18, 1965. It enables the foreign investor to enter into negotiations with the host country without recourse to his own government's sponsorship and should provide him with an additional guarantee. 10

Like the other economic measures introduced in October 1966, the Foreign Investment Law was also based on Decision No. 23 of the Provisional People's Congress, MPRS. ${ }^{11}$

9. Under the United States guarantee program, investors may choose the particular risks against which they wish to be guaranteed, expropriation, non-convertibility of currency or war, and pay premiums accordingly. High priority investments can also apply for "extended" risk insurance covering all types of risks. See, United Nations, Foreign Investment in Developing Countries (New York: United Nations, 1968), p. 25 .

10. Although more than fifty countries have signed this convention, Latin American countries are conspicuously absent from the list, as they reject any discrimination in favor of aliens as against host country's nationals and in their traditional Calvo clause require that foreign investors subject themselves to the jurisdiction of local tribunals. See, United Nations, The Status of Permanent Sovereignty over Natural Resources, Document No. A/AC.97/5, Chapter I.

11. Article 62 of "Decree No. XXIII concerning Renewal of Policy as to the Basis of the Economy, Finance and Development," Decisions of the Fourth Plenary Session of the Madjelis Permusjawaratan Rakjat Sementara 20th June to 5 th July 1966, English Edition (Djakarta: Department of Information, $\overline{1966) \text {. }}$. 
However, the law, which was approved by Parliament and promulgated as Law No. I of 1967 should be considered rather differently in purpose and intent from the October 1966 measures. These measures essentially constituted a crash program to deal with the galloping inflation and to rescue the economy from the accelerating downward trend of the previous years.

By its nature, the new foreign investment policy could not be made part of such a program as no foreign private capital can be forced to enter and help rescue a deteriorating economy. No matter how liberal a policy of encouraging foreign investment, the ultimate decision lies with the foreign investor and it is always easier to ban or expropriate capital than to persuade capital to enter a country. Thus, the new law should be seen more in its long term perspective. It was officially stated that 1967 and 1968 would be devoted to stabilization and rehabilitation measures and that economic development would only begin to be pursued in earnest with the launching of the Five Year Economic Development Plan in 1969. The contribution of foreign investment would be more apparent in the period of the five year plan.

The 1967 foreign investment $l$ aw is much more liberal than that of 1958. However, as high priority was given to the early passage of the bill, the law shows signs of haste and is still vague and ambiguous in certain respects. The government stated that executive policy would remove some of the uncertainties insofar as they stemmed from the imperfections of the law, as it preferred to wait for experience rather than rush to make detailed rules that could be unfortunate if proven too restrictive.

A series of supplementary regulations and laws were issued after January 1967. Among the more important ones was the regulation concerning the possibility of converting overdue foreign private claims into "foreign investment" rupiahs.12 Under this scheme, the many private creditors who have overdue claims inherited from pre-1965 times and are not guaranteed by foreign governments may convert their claims into special rupiahs, called Debt Investment Conversion Scheme or DICS rupiahs, which may be used for investing in Indonesia and can claim the same advantages as foreign investment. Such DICS rupiahs may also be sold to thind parties wanting rupiahs for local working capital, and finally DICS may be converted into foreign exchange for the purpose of importing equipment and raw materials needed

12. Instruksi Presidium Kabinet No. 28/EK/IN/5/1967 issued on May 10, 1967, and Basic Regulations Governing Debt Investment Conversion Scheme Rupiahs (DICS) issued by the Central Bank on September 6, 1967 . 
for the setting up or running of an enterprise.

Another important set of measures dealt with the return of foreign-owned enterprises expropriated under the previous regime, with the exception of Dutch enterprises taken over in 1957. The Dutch have agreed to accept compensation payments instead. In addition, laws granting incentives to returned enterprises similar to those for newly established foreign enterprises were promulgated. In some cases, the privileges granted are greater, such as the waiver of the $\$ 2.5$ million minimum for additional capital brought in by returned enterprises for expansion or rehabilitation. ${ }^{13}$

Meanwhile, to comply with complaints voiced by domestic private capital interests, the long awaited Law to Promote Domestic Capital was passed on July 3, 1968 as Law No. 6, 1968. The long delay in the passage of the law was caused by the controversy surrounding so-called "foreign domestic capital." It should be noted that the major part of private domestic enterprises and, therefore, of private domestic capital resources are in the hands of Chinese, many of whom, although having settled for generations in Indonesia, have opted for the citizenship of China after independence and are therefore foreigners. Enterprises owned by them are technically "foreign" enterprises but are given the special name of "foreign domestic" enterprises. ${ }^{14}$ This term originated in the previous era when such enterprises, though both private and foreign, were given a special place because they were ostensibly "progressive" in that they did not affect the balance of payments by repatriating capital or profits to China. The underlying reason, obviously, was political; the administration could hardly afford a deterioration in relations with China by nationalizing such private and "foreign" capital, especially between 19631965. Thus the late D. N. Aidit, who opposed all foreign capital, repeatedly defended the position of such "foreign domestic capital," which together with private national capital, he felt, should be given a prominent place in the struggle against imperialism. The same position was taken by Sukarno. ${ }^{15}$

13. Instruction No. IN/026 MEKKU/IV/1967 from the Presidium Minister for Economy and Finance, Djakarta, April 1, 1967. The pertinent law preceding it is the Cabinet Presidium Instruction No. 09/U/IN/2/1967 Regarding Restoration of Foreign Enterprises, February 6, 1967.

14. The distinction seems necessary as the source of such capital is always reinvested profits and never "inflow" from China.

15. See among others, D. N. Aidit, "Masalah Pengerahan Dana dan Tenaga ("Funds and Forces") Untuk Pembangunan," Ekonomi dan Masjarakat, Vol. VI, No. I (January-March 1964); Sukarno's speech of August 17, 1959, entitled "The Rediscovery of Our Revolution," which was promulgated as the Political Manifesto. 
The new law on the promotion of domestic capital covers both national and foreign domestic capital. It is in many respects more liberal than the foreign investment law and can be considered a supplement to it, as it removes certain uncertainties of the previous law. It should however be noted that in this law the word "foreign enterprise" essentially means foreign domestic enterprise as defined above.

Such foreign domestic firms, while they are to be given the same benefits as private national firms, are subject to many restrictions specifically mentioned in the law, especially regarding the length of their operation, which may be as short as ten years. In fact, the essential aim of Articles 6 and 7 of the law is eventually to end the dominant position of foreign domestic capital in the economy, while Article 23 stipulates that such capital cannot form a joint venture with a "genuine" foreign enterprise as defined by the 1967 foreign investment law. A subtle reversal has therefore been taking place in government policy regarding foreign "domestic" capital owned predominantly by resident but foreign Chinese.

It is interesting to note that $\$ 3.5 \mathrm{million}$ owned by Indonesian citizens of Chinese descent and now invested in Hong Kong is reportedly to be invested in five crumb-rubber processing plants in Indonesia. This capital will probably be considered domestic but national capital as it is owned by Indonesian citizens.

Implementation of the New Policy

The Foreign Investment Picture in 1966

As Dutch investment substantially dominated the scene up to the expropriations of 1957, the wave of take-overs of Dutch enterprises in that year had significant consequences on the economy. All Dutch enterprises were turned into state enterprises and 1957 therefore saw the birth of an important public sector in the Indonesian economy.

It is difficult to estimate the extent of such investment. partly because of differences in the method of valuation and partly because the Dutch were very reluctant to disclose the actual amount. In 1958, the Dutch Foreign Minister Luns estimated Dutch investments taken over in 1957 at 1,200 million dollars. In the final agreement reached between the Dutch and the Indonesian governments in 1967 on compensation payments for expropriated property, the total amount which Indonesia was to pay within a thirty year period was $\$ 157$ million (six hundred million guilders). 
In a report prepared by an American firm for the Indonesian government, the total amount of foreign investment in Indonesia in 1952 was estimated at $\$ 2,240 \mathrm{million}$ divided as follows: Dutch $65.6 \%$, American 15.6\%, British 11.7\%, French and Belgian 4.7\% with other foreign enterprises making up the rest.

The share of Dutch investments in the immediate pre-World War II period was also estimated at about two-thirds of total foreign capital. Total private investment by the Dutch at that time was estimated at $\$ 2,634$ million, broken down as follows: sugar $15.2 \%$, rubber $17.1 \%$, other agriculture $13.3 \%$, agricultural loan banks $10.4 \%$, tin mining $0.4 \%$, petroleum 19\%, shipping $3.8 \%$, railroads $5.7 \%$, public utilities $3.8 \%$, industry $1.9 \%$ and miscellaneous $9.5 \% .16$

Capital of other countries was mainly invested in plantations and petroleum mining. American capital was also invested in manufacturing, including a tire factory.

In the post-World War period, virtually no new private capital inflow from abroad took place with the exception of capital invested in the petroleum industry. While many companies rehabilitated their former holdings, no new expansion programs took place. As continued uncertainty prevailed on the foreign investment scene and Dutch-Indonesian relations continued to deteriorate, many Dutch firms even attempted to repatriate accumulated profits and capital investments.

Generally, foreign investment was in the export-oriented industries providing raw materials for the industrial centers of the world. Little attention was paid to investing in industrial projects or even in the further processing of agricultural and mineral products.

Ironically, the Sukarno sponsored production-sharing contracts were, by their very nature, always export-oriented and would, if allowed to develop extensively, have perpetuated Indonesia's position as a raw materials exporter and an importer of all kinds of consumer goods. This is because productionsharing contracts provided for repayments of credits from the products exported. Aside from the contracts in the petroleum industry, four projects of this nature had started exporting in 1966, including a nickel contract with Japanese interests, a logging project, a palm-oil project and a tin-dredging project. Including other contracts signed but not in the exporting stage, total investments under production-sharing contracts,

16. A. S. Keller, "Netherlands Indies as a Paying Proposition," Far Eastern Survey (January 17, 1940). Chinese capital was included, probably accounting for the bulk of the miscellaneous category. Dutch governmental capital in tin, railroads and public utilities was substantial. 
outside petroleum, amounted to $\$ 47.8$ million. Japan accounted for more than $50 \%$ of the total. ${ }^{17}$

These production-sharing contracts, together with oil companies' investments to be discussed in the next section and the foreign "domestic" investment which is actually not foreign capital in the common definition of the word, constituted the only categories of foreign private capital still operating in the country by 1966 .

\section{The Problems Confronting the Foreign Investor}

Judging from the quite substantial amounts of foreign capital for which investment permits were successfully applied during the years 1967 and 1968, the new investment policy of the government should be considered a promotional success. Apart from these efforts by the government, the many meetings sponsored by various foreign organizations on investment promotion in Indonesia have no doubt played a significant role in attracting prospective investors. Among the most important should be mentioned the Pacific Indonesia Business Association (P.I.B.A.) meeting sponsored by the Stanford Research Institute during August 2-5, 1967 in Djakarta. This meeting, attended by 170 business executives from 14 nations plus 90 Indonesian business executives and many senior officials of the government, had as its basic purpose the assessment of economic development needs, programs and opportunities in Indonesia and the examination of the policies, conditions and projects under which both domestic and foreign private enterprise could participate in Indonesia's economic development.

As a follow-up measure to the meeting, the P.I.B.A. Investment Promotion Council (P.I.B.A. - I.P.C.) was established by the Indonesian participants. The new council cooperates with government agencies in preparing feasibility studies, collecting pertinent information data and engaging in investment promotion in general. It has organized meetings in regional capitals of Indonesia like Surabaja and Makasar (and one to be held in a regional capital in Sumatra in early 1969) with the purpose of promoting investment in the regions outside Djakarta. ${ }^{19}$ As

17. Information provided by the Technical Committee on Capital Investment. For a comprehensive survey of production-sharing developments in Indonesia, see Joyce Gibson, "Production Sharing, I and II," Bulletin of Indonesian Economic Studies (February and June 1966).

18. The Djakarta Report.

19. "From Sydney to Djakarta," Annual Report 1968 of the P.I.B.A.I.P.C., mimeographed (Djakarta, January 1969). 
shown on Table 4, most manufacturing and other non-extractive investment projects are concentrated in Djakarta. An additional result of these meetings has been recommendations put before the government, such as those adopted at the Makasar meeting, to review existing corporation taxation and labor laws.

Two other meetings were arranged by the New York-based Business International in Geneva and Djakarta, in November 1967 and in September 1968 respectively. The Business and Industrial Advisory Council of the O.E.C.D. and the Japanese "Keidanren," a non-profit organization representing 729 large Japanese enterprises also held meetings in Djakarta during the second half of 1968 .

Apart from the obvious promotional benefits derived from them, these meetings also provided a useful forum for discussing the problems faced by foreign investors. As they were attended by high-level government officials, these discussions may prove to have been quite effective. For instance, the Business International meeting in Djakarta discussed the frequent changes in government regulations, particularly in the field of foreign trade, making it impossible for investors, especially in the manufacturing sector, to make cost calculations. The conference noted that manufacturers not tied to raw material supplies in Indonesia might find other locations to set up their plants. The conference also discussed the excessive administrative bureaucracy and the fact that procedures laid down by the central government are frequently ignored by regional authorities, who in addition levy their own taxes, thereby increasing the unattractiveness of doing business in Indonesia. Moreover, the confererice observed that hostile attitudes towards Chinese businessmen had resulted in a breakdown of marketing in some areas and that such discriminatory practices might in the future be turned to other non-Chinese foreigners. 20

The discussion above brings us to the problem of the motivation of the foreign investor. It is a well-known fact that the private capital flow to developed countries is much larger than that flowing to developing countries. ${ }^{2}$

20. Editorial on Foreign Investment, Business News (Indonesian edition, Djakarta, September 20, 1968). Also, Sanjoto, "Djakarta Forum," Far Eastern Economic Review (October 17, 1968).

21. For example, direct investment by United States business in foreign countries at the beginning of 1965 was estimated at $\$ 44.3$ billion, of which (in U.S.\$billion): 25.9 was in Canada and Europe, 8.9 in Latin America, 3.1 in Asia, 1.6 in Africa, 1.6 in Oceania, 1.4 in other Western Hemisphere and 1.9 internationally. U.S. Department of Commerce, quoted in: United Nations, The Role of Private Enterprise in Investment and Promotion of Exports in Developing Countries (New York: United Nations, 1968), pp. 14-15. 
The investors' main consideration, when investing abroad, is to earn a reasonable profit which should be higher than he can earn at home to compensate for the extra trouble and risk of operating abroad. Under these circumstances, it is interesting to examine the results of a world-wide survey on motivation conducted by Stanford Research International in 1961 in the light of the present Indonesian experience. ${ }^{22}$

The results of the survey indicate that the importance of factors in the considerations of foreign investors listed in order of rank is as follows:

1. Political stability.

2. Favorable government attitude towards private enterprise.

3. Economic stability.

4. Financial stability.

5. Favorable government attitude towards the profit motive.

6 . Degree of corruption within the government.

No numerical values, of course, can be attached to these essentially qualitative factors and it is impossible to determine to what extent each factor will contribute to a particular investment decision. Thus, while under the sukarno government political stability was probably more assured as no opposition was tolerated, other, lower ranking factors such as attitudes towards foreign investment, and more importantly, financial stability would have been rated very low as the rate of inflation in 1965 and 1966 assumed runaway proportions. ${ }^{23}$

By contrast, the present preoccupation with democratic and constitutional principles has permitted vociferous opposition to government policies. On the other hand, the postponement of general elections reflects the present government's belief that a return to the parliamentary procedures of 1950-1957 is not wanted at present as this would endanger the precarious political stability achieved.

However, all othe other factors have shown a favorable change in rating. Relative to 1965-1966, financial stability during 1967-1968 has significantly improved, as shown on Table 1, which shows that the rate of inflation and of depreciation of the rupiah, has been brought down considerably.

22. Harry J. Robison, The Motivation and Flow of Private Foreign Investment (Menlo Park, Calif.: Stanford Research Institute, (96I).

23. During 1965 and 1966, the consumer price index rose by 594 and 635 per cent respectively. Meanwhile, the free market rate of the rupiah to the dollar rose from 7,125 rupiahs per dollar to 50,000 rupiahs in 1965, and from 50 new rupiahs to 122 new rupiahs during 1966. (In January 1966, a revaluation of the rupiah took place which converted 1,000 rupiahs into one new rupiah.) 
Table. 1

Rate of Inflation and of Rupiah Depreciation

\begin{tabular}{|c|c|c|c|c|c|c|c|c|}
\hline \multirow[b]{3}{*}{ End of month } & \multicolumn{4}{|c|}{ Cost of living index } & \multicolumn{4}{|c|}{ Exchange rate movements } \\
\hline & \multicolumn{2}{|c|}{$\begin{array}{l}\text { Base } 1966 \\
\text { Sept }=100 \\
\end{array}$} & \multicolumn{2}{|c|}{$\begin{array}{l}\text { Monthly rate of } \\
\text { inflation }(\%)\end{array}$} & \multicolumn{2}{|c|}{$\begin{array}{l}\text { Rupiahs per } \\
\text { U.S. dollara }\end{array}$} & \multicolumn{2}{|c|}{$\begin{array}{c}\text { Monthly rate of } \\
\text { change }(\%) \\
\end{array}$} \\
\hline & 1967 & 1968 & 1967 & 1968 & 1967 & 1968 & 1967 & 1968 \\
\hline January & 145 & 395 & 9 & 40 & 131.0 & 297.5 & 7.4 & 2.6 \\
\hline February & 174 & 432 & 20 & 9 & 133.0 & 293.0 & 1.5 & -1.5 \\
\hline March & 180 & 445 & 3 & 3 & 122.5 & 305.0 & -7.9 & 4.1 \\
\hline Apriz & 181 & 419 & 0.5 & -6 & 127.0 & 340.0 & 3.7 & 11.5 \\
\hline May & 181 & 443 & 0 & 6 & 150.0 & 345.0 & 18.1 & 1.5 \\
\hline June & 187 & 455 & 3 & 3 & 157.0 & 360.0 & 4.7 & 4.3 \\
\hline July & 197 & 475 & 5 & 4 & 164.0 & 390.0 & 4.5 & 8.3 \\
\hline August & 201 & 492 & 2 & 3 & 167.0 & 400.0 & 1.8 & 2.6 \\
\hline September & 222 & 493 & 10 & 0.2 & 171.0 & 455.0 & 2.4 & 13.8 \\
\hline October & 238 & 487 & 7 & -1 & 173.0 & 485.0 & 1.2 & 6.6 \\
\hline November & 287 & 505 & 20 & 4 & 220.0 & 430.0 & 27.2 & -11.3 \\
\hline December & 283 & 523 & -1 & 4 & 290.0 & 420.0 & 31.8 & $-2 \cdot 3$ \\
\hline Annual rates: & & & +112.8 & +85 & & & +137.7 & +41.2 \\
\hline
\end{tabular}

a. Free market exchange rate.

Source: Cost of living index: Biro Pusat Statistik; Exchange rate: Pengumuman Sub Dewan Moneter, monthly government publication, various issues. 
Among the other factors, it is the sixth, or lowest ranking factor, the degree of corruption inherited from the previous hyperinflationary period, which has proved to be the most difficult to combat. True, corruption to a certain extent exists in most developing and in some developed countries and does not seem to be a major deterrent to the inflow of foreign capital, as evidenced by the low ranking the degree of corruption received in Stanford's survey. However, because of runaway inflation, wages and salaries in Indonesia are extremely low, even by developing countries'standards. This, coupled with an overgrown bureaucracy which plagues the present administration and the foreign investor alike, creates problems which may make this factor important enough to deter potential investors.

It is important to note, for instance, that only 10 per cent of Indonesia's civil servants receive salaries above $\$ 5.00$ (five dollars) a month plus a rice allowance for an average of five children. ${ }^{24}$ As a result, most provincial officials all participate in business, whether officially or unofficially. These officials are often in a position to retard or facilitate an investment project, regardiess of arrangements made and approval granted in the capital. As noted earlier, despite national exemption laws, local governors may assess local taxes of which the foreign investor is not aware when the permit to invest is granted.

Another problem is the time involved in the establishment of a corporation. A local enterprise desirous of joining a joint enterprise with a foreign company will have to liquidate and form a new company, a procedure which may take months to accomplish. ${ }^{5}$

Now that the government's stabilization policies have shown. indications of success, a reorganization of the state apparatus coupled by significant salary increases will indirectly go a long way towards combatting corruption. But under present circumstances, where, as a result of prolonged and severe inflation, the widespread corruption has in most cases been caused by unrealistically low salaries, repressive measures taken to combat corruption will only lead to endless charges and counter-charges, resulting in total confusion and demoralization.

Reorganization of the state apparatus is being implemented vigorously, by merging various government departments, by reallocation of civil servants to departments where there is more work to do, and by a massive lay-off of surplus civil servants. It should be noted that the civil service has grown from 420,000

24. "The Deadwood Still Unlopped," Economist (October 19, 1968).

25. Moh. Sadli, "Laporan Perkembangan Penanaman Modal Asing Sampai Achir Djuli 1968," mimeographed. 
in 1950 to 2.4 million at present. Many state enterprises such as Garuda Indonesian Airways and the State Shipping Line are laying off workers in large numbers. In the latter case, more than half of the total employees of the enterprise were recently discharged. It is to be hoped that the many new foreign in vestment projects will be able to absorb at least part of these workers, for they are swelling the large ranks of the unemployed.

Finally, the conference discussed the problem of high tax rates in Indonesia. While companies coming under the exemption law do not pay corporate tax during the grace period, corporate tax rates, which are graduated from 20 to 60 per cent with the latter applicable to profits exceeding Rp. 7.5 million, were considered excessive. The high tax rates were considered necessary to insure enough revenues to the government in view of the high incidence of tax evasion. This in turn is a legacy of the past era of runaway inflation when only 250,000 people paid direct taxes out of a population of 115 million, the rest paying only indirect taxes and numerous semi-legal and illegal levies, which, however, were felt as quite substantial, as salaries of the government officials sank to incredibly low levels. While efforts to increase the tax base to about 600,000 people in 1968 has met with some success, only a thorough overhaul of the tax collection machinery and improvement in civil servants' salaries, resulting in an elimination of illegal levies, will convince the citizenry of its obligation to pay taxes.

\section{Sectoral Analysis of New Investment Projects}

The highest authority for decisions on foreign investments is vested in an Advisory Body for Foreign Capital Investment or Investment Council chaired by the president himself and consisting of cabinet ministers concerned with economics and finance. In its day-to-day operations, this body is assisted by the Technical Committee on Capital Investment, popularly known as the Foreign Investment Board. ${ }^{26}$

Generally, an application for a permit to operate under the foreign investment law is forwarded to the government department concerned which then seeks the assistance of the Foreign Investment Board to prepare a recommendation to be submitted to the Investment Council for final approval. If this

26. Established on September 26, 1968 by. Presidential Decree No. $286 / 1968$, the Committee consists of two sections dealing with foreign and domestic investment respectively. It incorporates the Technical Team on Eoreign Investment established by the Cabinet Presidium Decision No. 17/EK/Kep I/ 1967 on January 19, 1967. 
is obtained, the minister concerned is authorized to execute the permit on behalf of the government.

Regarding the legal status of companies operating in Indonesia, the government requests such corporations to acknowledge that its activities are governed by Indonesian laws and to appoint a registered agent and maintain a registered office in Indonesia. If operations in Indonesia are larger than the operations of the company in its country of origin, the company must establish a corporate body legalized under Indonesian law. 27

Up to the end of September 1968, foreign investment applications approved according to the above procedure numbered 84 , involving a total of $\$ 342.13$ million. ${ }^{28}$ This excludes foreign investment in banking, in petroleum and gas and the capital of returned foreign enterprises taken over under the previous regime. It does, however, include proposed new investments for rehabilitation or expansion by such returned enterprises as Unilever ( $\$ 1.5$ million) and Goodyear ( $\$ 13$ million). It is interesting to note that the Dutch company Philips will undertake a joint venture involving 25 million Dutch guilders with the state enterprise Ralin which was originally established to take over the investments of Philips expropriated in 1957. Table 2 gives the sectoral composition of foreign investment projects approved up to the end of september 1968, while Table 3 shows a breakdown of these projects by country of origin and type of project. Table 3 shows the United States leading the list in terms of number of projects, followed by the Netherlands and Japan. In terms of capital committed, the United States is followed by Canada and South Korea. It is interesting to note from the table that foreign investment applications have come from many developing as well as developed countries, reflecting the interest shown internationally in Indonesia's new "open door" policy. The following pages will analyze the investment projects by sector.

Mining. The largest proportion of total investment committed goes to the mining sector, although at present only three companies are involved: Freeport Sulphur of the United States, the Billiton Maatschappij of the Netherlands and the International Nickel Company of Canada, exploring copper, tin and nickel deposits respectively. Total investments for explorations to be made by the three companies amount to only four million dollars, a fraction of the intended $\$ 158.5$ million they will invest for further development if warranted by the exploration findings.

27. Investment, Government of Indonesia, Department of Information, 1968, p. 17.

28. Information supplied by the Technical Committee on Capital Investment. The figure for the end of 1968 was $\$ 365.12$ million. 
Table 2

Foreign Investment Projects by Sector and Size of Capital

(Up to the end of September 1968)

\begin{tabular}{|c|c|c|c|c|c|c|c|c|c|c|c|c|c|}
\hline & \multicolumn{4}{|c|}{ Total } & \multicolumn{3}{|c|}{$\begin{array}{c}\text { Projects smallen than } \\
\text { US } \$ 1 \text { million }\end{array}$} & \multicolumn{3}{|c|}{$\begin{array}{l}\text { Projerts between US \$1 } \\
\text { million and } 2 \text { million }\end{array}$} & \multicolumn{3}{|c|}{$\begin{array}{l}\text { Projects of US } \$ 2.5 \\
\text { million or more }\end{array}$} \\
\hline & $\begin{array}{l}\text { No.of } \\
\text { pro- } \\
\text { jects }\end{array}$ & $\begin{array}{c}\text { Capi- } \\
\text { tal } \\
\text { in mn. } \\
\$ \$\end{array}$ & $\begin{array}{c}\text { Average } \\
\text { capital } \\
\text { per } \\
\text { project } \\
\text { in m. } \$\end{array}$ & $\begin{array}{l}\text { Per } \\
\text { cent } \\
\text { of } \\
\text { total }\end{array}$ & $\begin{array}{l}\text { No.of } \\
\text { pro- } \\
\text { jects }\end{array}$ & $\begin{array}{c}\text { Capi- } \\
\text { tal } \\
\text { in } \mathrm{mn} . \\
\$ \$\end{array}$ & $\begin{array}{c}\text { Average } \\
\text { capital } \\
\text { per } \\
\text { project } \\
\text { in mn. }\end{array}$ & $\begin{array}{l}\text { No.of } \\
\text { pro- } \\
\text { jects }\end{array}$ & $\begin{array}{c}\text { Capi- } \\
\text { tal } \\
\text { in } m \text {. } \\
s\end{array}$ & $\begin{array}{c}\text { Average } \\
\text { capital } \\
\text { per } \\
\text { project } \\
\text { in mn.\$ }\end{array}$ & $\begin{array}{l}\text { No.of } \\
\text { pro- } \\
\text { jects }\end{array}$ & $\begin{array}{c}\text { Capi- } \\
\text { tal } \\
\text { in mn. } \\
\$\end{array}$ & $\begin{array}{l}\text { Average } \\
\text { capital } \\
\text { per } \\
\text { project } \\
\text { in mn. }\end{array}$ \\
\hline 1. Mining & 3 & 158.5 & 52.8 & 46.3 & -- & -- & -- & -- & -- & -- & 3 & 158.5 & 52.8 \\
\hline 2. Forestry & 13 & 79.5 & 6.1 & 23.1 & -- & -- & -- & 7 & 12.0 & 1.7 & 6 & 67.5 & 11.2 \\
\hline $\begin{array}{l}\text { 3. Manufac- } \\
\text { turing }\end{array}$ & 43 & 66.7 & 1.6 & 19.5 & 22 & 7.6 & 0.3 & 16 & 23.0 & 1.4 & 5 & 36.2 & 7.2 \\
\hline $\begin{array}{l}\text { 4. Communica- } \\
\text { tions and } \\
\text { public works }\end{array}$ & 11 & 16.9 & 1.5 & 5.0 & 6 & 0.7 & 0.1 & 1 & 2.0 & 1.0 & 4 & 14.2 & 3.6 \\
\hline 5. Fisheries & 7 & 11.5 & 1.6 & 3.4 & -- & -- & -- & 5 & 6.5 & 1.3 & 2 & 3.0 & 2.5 \\
\hline 6. Plantations & 4 & 6.9 & 1.7 & 2.0 & 2 & 0.9 & 0.5 & 1 & 1.0 & 1.0 & 1 & 5.0 & 5.0 \\
\hline 7. Commerce & 3 & 2.1 & 0.7 & 0.6 & 2 & 1.0 & 0.5 & 1 & 1.1 & 1.1 & -- & -- & -- \\
\hline Total & 84 & 342.1 & 4.1 & 100 & 32 & 10.17 & 0.3 & 31 & 45.6 & 1.5 & 21 & 286.4 & 13.6 \\
\hline
\end{tabular}

Source: Technical Committee on Capital Investment: Sub Committee on Foreign Investment. 
Table 3

Foreign Investment Projects by Sector and Country of Origin

(Up to the end of September 1968)

\begin{tabular}{|c|c|c|c|c|c|c|c|c|c|c|c|c|c|c|c|c|}
\hline & \multicolumn{2}{|c|}{ Total } & \multicolumn{2}{|c|}{$\begin{array}{c}\text { Manufac- } \\
\text { turing } \\
\end{array}$} & \multicolumn{2}{|c|}{ Mining } & \multicolumn{2}{|c|}{ Forestry } & \multicolumn{2}{|c|}{ Fisheries } & \multicolumn{2}{|c|}{$\begin{array}{l}\text { Communica- } \\
\text { tions and } \\
\text { public works }\end{array}$} & \multicolumn{2}{|c|}{ Plantations } & \multicolumn{2}{|c|}{ Commerce } \\
\hline & $\begin{array}{l}\text { No.of } \\
\text { pro- } \\
\text { jects }\end{array}$ & $\begin{array}{l}\text { Capi- } \\
\text { tal } \\
\text { in mn. } \\
\quad \$\end{array}$ & $\begin{array}{l}\text { No.of } \\
\text { pro- } \\
\text { jects }\end{array}$ & $\begin{array}{c}\text { Capi- } \\
\text { tal } \\
\text { in } \mathrm{mn} . \\
\$ \$\end{array}$ & $\begin{array}{l}\text { No.of } \\
\text { pro- } \\
\text { jects }\end{array}$ & $\begin{array}{l}\text { Capi- } \\
\text { tal } \\
\text { in } \mathrm{mn} . \\
\$\end{array}$ & $\begin{array}{l}\text { No.of } \\
\text { pro- } \\
\text { jects }\end{array}$ & $\begin{array}{c}\text { Capi- } \\
\text { tal } \\
\text { in } \mathrm{mn} . \\
\$ \$\end{array}$ & $\begin{array}{l}\text { No.of } \\
\text { pro- } \\
\text { jects }\end{array}$ & $\begin{array}{c}\text { Capi- } \\
\text { tal } \\
\text { in } \operatorname{mn} . \\
\$\end{array}$ & $\begin{array}{l}\text { No.of } \\
\text { pro- } \\
\text { jects }\end{array}$ & $\begin{array}{c}\text { Capi- } \\
\text { tal } \\
\text { in mn. } \\
\$ \$\end{array}$ & $\begin{array}{l}\text { No.of } \\
\text { pro- } \\
\text { jects }\end{array}$ & $\begin{array}{c}\text { Capi- } \\
\text { tal } \\
\text { in mn. } \\
\$ \$\end{array}$ & $\begin{array}{l}\text { No.of } \\
\text { pro- } \\
\text { jects }\end{array}$ & $\begin{array}{l}\text { Capi- } \\
\operatorname{tal} \\
\text { in mn. } \\
\$ \$\end{array}$ \\
\hline 1. U.S.A. & 12 & 114.6 & 7 & 25,1 & 1 & 76.5 & -- & -- & -- & -- & 3 & 11.5 & 1 & 0.4 & 1 & 1.1 \\
\hline 2. Canada & 3 & 75.9 & 2 & 0.9 & 1 & 75.0 & -- & -- & - & -- & -- & -- & -- & -- & - & -- \\
\hline 3. South Korea & 1 & 48.5 & -- & -- & -- & - & 1 & 48.5 & -- & -- & -- & -- & -- & -- & -- & -- \\
\hline 4. Netherlands & 12 & 19.4 & 6 & 10.8 & 1 & 7.0 & 1 & 1.5 & -- & -- & 2 & 0.3 & -- & - & 2 & 1.0 \\
\hline 5. Japan & 10 & 17.2 & 3 & 4.2 & -- & - & 3 & 6.5 & 4 & 6.5 & -- & -- & -- & $\therefore$ & - & -- \\
\hline 6. Philippines & 4 & 12.5 & -- & -- & -- & -- & 3 & 11.0 & 1 & 1.5 & -- & -- & -- & -- & -- & -- \\
\hline 7. Hong Kong & 10 & 11.1 & 7 & 3.9 & -- & -- & 1 & 6.0 & -- & -- & 1 & 0.3 & 1 & 1.0 & -- & -- \\
\hline 8. Panama & 1 & 9.0 & 1 & 9.0 & -- & -- & -- & -- & -- & -- & -- & -- & -- & -- & -- & -- \\
\hline 9. West Germany & 5 & 5.6 & 5 & 5.6 & -- & -- & -- & -- & -- & -- & -- & -- & -- & -- & -- & -- \\
\hline 10. Belgium & 3 & 5.5 & 2 & 0.6 & -- & -- & -- & -- & -- & -- & -- & -- & 1 & 5.0 & -- & -- \\
\hline 11. France & 2 & 5.0 & -- & -- & -- & -- & 1 & 2.5 & -- & -- & 1 & 2.5 & -- & -- & -- & -- \\
\hline $\begin{array}{l}\text { Total } 11 \text { coun- } \\
\text { tries }\end{array}$ & 63 & 324.3 & 33 & 60.1 & 3 & 158.5 & 10 & 76.3 & 5 & 8.0 & 7 & 14.6 & 3 & 6.4 & 3 & 2.1 \\
\hline other countries ${ }^{a}$ & 21 & 17.8 & 10 & 6.6 & -- & -- & 3 & 3.2 & 2 & 3.5 & 4 & 2.3 & 1 & 0.5 & -- & - \\
\hline Total & 84 & 342.1 & 43 & 66.7 & 3 & 158.5 & 13 & 79.5 & 7 & 11.5 & 11 & 16.9 & 4 & 6.9 & 3 & 2.1 \\
\hline
\end{tabular}

a. Other countries include United Kingdom, Singapore, Switzerland, Denmark, Australia, Norway, Malaysia and Kuwait.

Source: Technical Committee on Capital Investment: Sub Committee on Foreign Investment. 
Meanwhile, many other companies are negotiating concessions for the mining of nickel, bauxite, tin and other minerals in areas declared open for exploration. Among the most important are the negotiations going on with Alcoa of the United States, which has initialled an agreement with the government for the exploration and subsequent development of bauxite deposits in Indonesia. No specific area is mentioned in the agreement, but Alcoa will conduct a comprehensive survey involving $\$ 9.5$ million and is expected to invest, if warranted by the survey, at least $\$ 100$ million in the production of aluminum, including the construction of an aluminum plant on Bangka island. Two other nickel projects, a Dutch-U.S.-Canadian and a Japanese consortium are vying for nickel contracts in the West Irian and Moluccas areas respectively. If the three nickel groups start producing, Indonesia's output is expected to be stepped up considerably from present production of 170,602 tons in 1967, and 170,386 tons in the first eight months of 1968. This will make nickel a major new source of export earnings for Indonesia. Alcoa's contract will also make Indonesia a significant producer of bauxite and aluminum, as at present it produces and exports only close to one million tons of unrefined bauxite a year. On the other hand, large-scale stepping up of tin production may pose problems in the light of recent export quotas and restrictions and the threat of another steep decline in tin prices. Indonesia's tin production has steadily declined, from 18.5 thousand tons in 1961 to a low of 12.8 thousand tons in 1966. January to August 1968 production totalled 10.7 thousand tons. It is therefore very unfortunate that export quotas are being clamped on producers when Indonesia is on the verge of regaining her former position in the industry.

Forestry. The second largest sector is forestry, a relatively new industry in Indonesia. Conspicuous among the applicants are those coming from other Asian countries, and one single project, that of the Korea Development Company, accounts for $\$ 48.5$ million of the total, as shown in Table 3 . It is significant that the Philippines and South Korea, themselves exporters of lumber and plywood, figure prominently among the investors.

This is not surprising in view of the declining supplies in the Philippines, which also account for the intensified efforts of Japanese plywood companies to obtain Indonesian supplies. The total hardwood timber inventory of Indonesia is estimated at about 413 billion cubic feet, on more than 13 times that of the Philippines. ${ }^{2}$

About one-third of Indonesia's 120 million hectares of timberland is considered accessible, but logging activities at present cover only 5 miliion hectares. Although at present

29. Stanford Research Institute, Indonesia (Menlo Park, Calif.: Stanford Research Institute, $\overline{1967), ~ p .} 22$. 
about 95 per cent of Indonesia's consumption of paper, hardboard and plywood is imported, the immediate future will see, judging from foreign investment projects so far approved, more emphasis on logs and lumber exports rather than the establishment of forest-based industries, both for domestic consumption and for exports. By the end of 1968, an estimated 50 concessions involving 7 million hectares are expected to be granted. Holders of concessions of over 40,000 hectares are required to establish, in stages, sawmills, veneer and plywood factories and finally pulp and paper factories. ${ }^{30}$

Manufacturing. Though manufacturing ranks third in total capital, it attracts the largest number of projects, reflecting a low average capital investment per project. ${ }^{31}$ While most projects are in import-substituting industries, there are a few export-earning industries, such as the manufacture of hairwigs, instant coffee and crumb-rubber. The recently announced intention to ban all car imports except in knocked-down status will provide a stimulus to the establishment of car assembly factories. In view of the potential market of 115 million people, interest in the manufacturing industry so far has been rather disappointing and may await further promotional activities from the government, as will be discussed later.

Communications and Public Works. This category includes a satelifte communications project of I.T.T. and several aviation companies' plans to operate internal services in Indonesia. While the introduction of new services to supplement the often quite inefficient domestic services of the Garuda in the past should be welcomed, an indiscriminate granting of licenses to numerous small companies may again result in inefficient competition and operating losses. According to a Communications Department report, fifteen private airline companies have been granted Iicenses in Indonesia, of which six have started operation.

Plantations. This sector, together with mining traditionally the most important foreign investment sector, has so far attracted little attention from potential investors. In view of declingin raw material prices in general, and rubber prices in particular, this should be expected, The same holds true for Malaysia. Although Malaysia still expects to expand rubber and palm-oil acreage and production considerably, such expansion will take place in government-sponsored land-clearance projects rather than in private estates' acreage.

30. Mohamad Sadli, Laporan Penanaman Modal Asing Sampai Achir Djuli 1968, mimeographed.

31. In Tables 2,3 and 4, the manufacturing sector incorporates pharmaceutical, which in the original tables supplied by the Technical Committee constitutes a separate category. 
Meanwhile, several companies have shown interest in banana and maize plantations, both new fields for Indonesia but both rapidly expanding commodities in international trade.

other sectors. Among the other sectors, projects in fisheries will be important in their contribution to export earnings. Shrimps, a rapidly growing international trade commodity, attract the most attention, as American and Japanese companies have obtained concessions. Tourism has so far not attracted serious investors. Judging from the potential in this field and the shortage of hotel and other facilities in Djakarta and in other Indonesian towns, tourism projects will most probably become more important in the future.

Banking. As stated earlier, foreign investment in banking is regulated under separate laws, and permits are granted under a different system. Up to the end of November 1968 , eleven foreign banks, from the U.S.A., Japan, Thailand and other countries, have been granted approval, eight of which have started operations. Five more banks have submitted their applications. All banks must bring in a minimum of $\$ 1$ million in order to qualify.

Petroleum and Gas. Petroleum will continue to be one of Indonesia's major export earners in the future and prospects for considerably increasing exports from this source seem to be the brightest, considering both international demand trends and domestic developments in production. Despite the moratorium on exploration between 1939 and 1963 and despite the stipulation of the law of 1960 that oil and gas production should be vested in state enterprises which may appoint foreign companies as "contractors," oil production continued to increase throughout the postwar period, and foreign enterprises continued to play a major role.

At present, the largest producer is Caltex, producing 360,000 barrels per day or about 70 per cent of total production in 1967. Caltex, together with Stanvac, operate under the 1963 agreement which essentially granted the three major operating companies ${ }^{32}$ a twenty year period of development of their old fields as well as thirty year contracts for new explorations in new areas in return for their being reduced to "contractors" and for surrendering their old concessionary rights. ${ }^{3}$

32. The third, Shell Company, sold its entire interests to the Indonesian government in January 1966, during the chaotic aftermath of the 1965 coup. Negotiations for the purchase of the other two companies were terminated following the major shift in Indonesia's economic policy.

33. For details of the agreement, see Alex Hunter, "The Oil Industry: The 1963 Agreements and After," Bulletin of Indonesian Economic Studies (September 1965), PP. 16-34. 
Meanwhile, the reversal in government policy towards new foreign investment has attracted many new petroleum companies. Contracts for exploration and subsequent drilling, mostiy in offshore areas, number twenty at the time of writing, mainly involving American and Japanese companies. These are predominantly small or medium-sized companies although three large international firms, Mobil of the U.S., C.F.P. of France and E.N.I. of Italy, have also shown interest. The predominance of small companies can be explained by the fact that foreign investment in oil is still governed by the stiff conditions of the 1960 Law No. 44 which provides essentially for productionsharing "contracts." Under these contracts, the foreign companies retain 40 per cent of crude production for exploration work and production costs. The remaining 60 per cent "profits" is divided into the ratio of $65: 35$ (in some cases $67 \frac{1}{2}: 32 \frac{1}{2}$ )

between the state oil enterprise Pertamina and the oil company, in favor of the former.

The results of all these new activities in oil will only be felt after 1970. However, production and exports from oil have already increased by large amounts in the last two years. Net receipts from oil exports increased by 21 per cent in 1968 , and are expected to increase by 33 per cent in the 1969-1970 fiscal year. ${ }^{34}$ This increase has mainly been contributed by Caltex Oil Company which invested substantially in development drilling and construction of storage facilities which enabled it to step up production considerably. Caltex' new investments were prompted by a successful negotiation of a reduction in its crude oil prices with the Indonesian government. ${ }^{35}$

Problems of Location. Table 4 shows the distribution of investment projects by location. By far the largest number of projects are located in Djakarta, especially in manufacturing, with the rest located in Java outside Djakarta. Projects located on the other islands are in extractive industries or plantations, which of necessity must be located where they are. With regard to location, it is officially stated that the government decides the site on which the plant is located in conformity with the development plan. In the case of mining, fisheries and forestry projects, the government generally offers tracts or blocks for tender. Article 6 of the Directives on Determining Priorities grants additional exemption of taxes for one year to companies investing outside Java.

Foreign Investment and the Five Year Development Plan

At the end of 1968 the president officially declared the recently completed Five Year Plan to be the official basis for

34. Preliminary estimates from Bank Negara Indonesia Unit I.

35. Information provided by the Directorate-General of $0 i l$ and Gas. 
Foreign Investment Projects by Sector and Location

(Up to the end of September 1968)

\begin{tabular}{|c|c|c|c|c|c|c|c|c|}
\hline & \multicolumn{2}{|c|}{ Djakarta } & \multicolumn{2}{|c|}{$\begin{array}{c}\text { Java outside } \\
\text { Djakarta } \\
\end{array}$} & \multicolumn{2}{|c|}{ Other islands } & \multicolumn{2}{|c|}{ Total } \\
\hline & Number & $\begin{array}{l}\text { Total in } \\
\text { mn. \$ }\end{array}$ & Number & $\begin{array}{l}\text { Total in } \\
\mathrm{mn} \text {. \$ }\end{array}$ & Number & $\begin{array}{l}\text { Total in } \\
\text { mn. \$ }\end{array}$ & Number & $\begin{array}{l}\text { Total in } \\
\text { mn. } \$\end{array}$ \\
\hline 1. Mining & -- & -- & -- & -- & 3 & 158.5 & 3 & 158.5 \\
\hline 2. Forestry & -- & -- & -- & -- & 13 & 79.5 & 13 & 79.5 \\
\hline 3. Manufacturing & 31 & 44.9 & 11 & 19.8 & 1 & 2.0 & 43 & 66.7 \\
\hline $\begin{array}{l}\text { 4. Communications } \\
\text { and public } \\
\text { works }\end{array}$ & 10 & 16.4 & -- & -- & 1 & 0.5 & 11 & 16.9 \\
\hline 5. Fisheries & -- & -- & -- & -- & 7 & 11.5 & 7 & 11.5 \\
\hline 6. Plantations & -- & -- & -- & -- & 4 & 6.9 & 4 & 6.9 \\
\hline 7. Commerce & 3 & 2.1 & -- & -- & -- & -- & 3 & 2.1 \\
\hline Total & 44 & 63.4 & 11 & 19.8 & 29 & 258.9 & 84 & 342.1 \\
\hline
\end{tabular}

Source: Technical Committee on Capital Investment: Sub Committee on Foreign Investment. 
government policy in the next five years. ${ }^{36}$

Foreign investment is to play a major role in the plan and in fact, for almost every industry, as indicated in the second volume of the plan, estimates of expected foreign investment inflows are included. Foreign investment is expected to contribute mainly in three ways. It will contribute to capital formation and therefore to the financing of the plan. It will have favorable repercussions, whether directly or indirectly, on the balance of payments. It will improve production techniques in the broadest sense of the word, including technological, managerial and administrative skills, all of which have suffered badly during the past period of runaway inflation. While this may very well be the most important contribution of foreign investment, it is a contribution very difficult to measure quantitatively and the remaining sections of this paper will concentrate on discussing the financial and balance of payments implications of foreign investment policy.

Financing the Plan and the Scale of Priorities

The plan in its present form is essentially only a partial plan in that it does not identify macro-economic variables such as gross national product or capital formation. Instead, output targets for strategic commodities in all sectors of the economy are set and the corresponding investment program is then matched against that part of domestic and foreign resources which is more or less amenable to government control or lends itself to estimation, such as foreign investment inflow, rather than against an estimate of aggregate and sectoral savings for the whole economy. As such, the plan includes both the government sector and a significant part of expected private investment. This approach was considered necessary for the present as aggregate data on the whole economy are lacking and the recent experience of runaway inflation has distorted basic economic relationships to such an extent that presently available estimates of aggregate variables cannot be useful. As a result of prolonged inflation, capital formation as a percentage of Gross National Product, for instance, has dropped to very low levels. An unpublished study has estimated this ratio to vary between 6.6 and

36. Presidential Decree No. 319/1968 on the Five Year Development Plan, Djakarta, December 30, 1968. The Indonesian version of the plan, called Rentjana Pembangunan Lima Tahun 1969/70-1973/ 74 (Five Year Development Plan), hereafter cited as REPELITA, was published in three volumes: Volume I, General, Volume II (in three books), Sectoral Plans, and Volume III, The Plan Details by Region, (Djakarta: Government of Indonesia, December 1968). Note: Indonesia, beginning in 1969, will change its fiscal year from the calendar year to the year from April 1 to March 31 . 
9.0 per cent during the period 1960-1966.

Table 5 shows the basic financial sources of the plan and the sectoral distribution of plan expenditures. The plan investment figure still shows the predominance of the government sector but shows also the important role to be played by private investment, mainly private foreign investment. The private investment target of 266 billion rupiahs, or 18.7 per cent of total investment, is probably too low, but, as stated earlier, it does not include all private investment. It is, of course, very difficult to estimate the course of private investment in the absence of reliable data on past experience and in the light of the major changes in economic policy and economic conditions which are still taking place.

The table also reflects the shift in government policy. While total development expenditures undertaken by the state are quite large, it is obvious that the government intends to confine itself primarily to providing social services and to concentrating on agriculture, mainly intensification of food production and infrastructural development, leaving other commodity production sectors to private, especially private foreign investment. While state enterprises are expected to continue playing a major role, especially in the field of wholesale trade and communications, such enterprises are expected to be operated on the same basis as private enterprise and cannot expect the large subsidies or special credits of the past.

Under these circumstances, the success of the plan will depend very much not only on the total amount of private foreign investment the government is able to attract, but also on its ability to channel such investment, through fiscal and regulatory measures, into the desired areas indicated by the scale of priorities of the plan.

In the scale of priorities adopted by the plan, agriculture receives the major emphasis, and the development of other sectors is to be geared to the requirements of agriculture. The plan gives secondary priority to foreign-exchange creating and foreign-exchange savings projects and tertiary priority to development of the infrastructure. Thus both export-promoting and import-substituting industries are to be given special stress in the plan. ${ }^{37}$

By comparison, the scale of priorities adopted for the new foreign investment policy shows in essence the following order of importance: export-promotion projects, import-substitution projects and thirdly, quick-yielding projects which create employment or are beneficial because of their effect on improving production techniques.

37. REPELITA, Volume I, PP. I-7 to I-11. 
Table 5

Financing the Five Year Plan

(All Figures in Billions of End of 1968 Rupiahs)

\section{Sources of Finance}

A. Government \& Foreign Aid

1. Government budgetary savings

2. Counterpart funds of Foreign Program Aid

393

3. Foreign Project Aid

Total

$\overline{1,059}$

B. Other Sources

1. Increases in intermediate and long term bank credits

2. Reinvestment profits, foreign, domestic, and state enterprises investments

Total

Grand total
266

361

1,420
95

1. Agriculture

2. Mining and Manufacturing

3. Communications and tourism Total

Grand total
319

130

3. Electricity 100

4. Communications \& Electricity 230

5. Community Development 50

6. Social \& General Projects
1,420

Source: REPELITA, Volume I, Chapter III. 
Leaving out the production of foodstuffs, which is clearly to receive emphasis in the government development budget, there remain the twin objectives of export-promoting industries and import-substituting industries which appear in both scales of priorities. The problems of which of these two should receive the main emphasis when attracting foreign investment is not easily solved. Apparently, under the "open door" policy of the past two years, when no specific directives were given as to the form of investment preferred, foreign capital has clearly shown a preference for investment in export-earning rather than in import-substituting industries.

In this field, again, the emphasis has been more on extractive industries, including mining, forestry and fisheries, than on exports of manufactures or the processing of raw materials. Thus the traditional foreign investment pattern, against which, historically, complaints of foreign domination and colonial patterns of development were mainly levelled, appears still to be prevailing, at least in the first two years of the new policy.

Of course, export-promotion is a very important objective in economic development, and is, in the present stage of the economy, probably more important than import-substitution. Moreover, even if the above pattern is not ideal, it will undoubtedly bring concrete benefits to the economy and is certainly to be preferred over the course taken during the pre-1966 period, in which neither the government nor foreign investors were exploiting the forests and mineral resources through endless indecision and verbal semantics on the merits and demerits of passing a foreign investment law, resulting in such natural resources remaining untapped for over twenty years.

The emergence of the "traditional pattern of investment" stems directly from the foreign investment act itself which in many respects is even more liberal than that of Indonesia's closest neighbors. In the 1956 Pioneer Industries Act of Malaysia, for instance, only manufacturing industries can qualify for "pioneer" status. This act was replaced by a new Investment Incentive Act in 1968, in which the definition was broadened to include any kind of commercial undertaking, although industries processing commodities for export are still favored. The Philippines Investment Incentives Act, promulgated in 1967 (Republic Act 5186), was also accompanied by an Investment Priority Plan in which industries to be granted preferred or preferred pioneer status, including total capacities of production, were specified. Import-substitution in the Philippines had, of course, received special protection during the period before decontrol in 1962. By contrast, the Indonesian act stipulates that all foreign enterprises approved in 1967-1968 are granted pioneer status, qualifying for additional tax exemption privileges. 
It is understandable that foreign enterprises in minerals and extractive industries are easier to attract than those in manufacturing. 'Nevertheless, the general trend among developing countries in attracting foreign investment at present is directed towards diversifying their largely raw materials based economies by the domestic processing of raw materials, the introduction of import-substituting and export-creating manufacturing industries as well as through the development of tourism.

If Indonesia appears to be an exception to this general trend, it is because the past two years saw a preoccupation of the government with measures to combat inflation and to stem the downward drift of exports and consequent balance of payments difficulties. With the background of expropriation without compensation and the generally hostile attitude towards foreign capital in the pre-1966 era still fresh in everyone's mind, a too restrictive foreign investment law would probably have had no success at all in attracting foreign capital. Now that the stabilization program has shown indications of success, there is no reason why the promotional campaign should not be directed towards attracting more import-substituting industries together with the objective of export-promotion.

Development of industrial estates and the undertaking of pre-investment surveys by the government for specific industries will encourage potential investors. The Department of Basic and Light Industries and Power has published a list of 94 projects in various manufacturing sectors declared "open" to foreign investors. ${ }^{38}$ Many of these projects were originally envisaged as state projects and some of them, such as the Tjilegon steel Plant, are now substantially completed with predominantly Eastern European aid, which has in most cases been terminated. This list may form the basis of an investment-priority plan in manufacturing and may be expanded to include preinvestment data on the likely development of markets, the degree of protection from foreign competition and other pertinent information.

In order to encourage foreign investment in manufacturing, joint ventures in this field will only mean that at least ten per cent of the capital should be Indonesian if the partner is a private company. In case the joint venture is undertaken with a state enterprise, the equity ratio becomes 50:50.

Protection from foreign competition is, of course, one of the major policy devices in promoting import-substituting industries. Domestic industries suffered heavily when foreign

38. Department of Basic and Light Industries and Power, Policy on Foreign Capital Investment in the Field of Basic, Light Industries and Power (Djakarta, 1968). 
exchange regulations were drastically liberalized in October 1966, and imports of consumer goods poured in as the multiple exchange rates prevailing up till then were virtually abolished. Protection in the form of higher tariffs and favorable prepayment conditions for raw materials and capital goods imports were only gradually re-introduced in 1968. This is reflected in the composition of consumer-goods imports which will be analyzed later.

\section{Balance of Payments Implications}

The policy of the pre-1966 era in accepting credits while objecting to equity foreign investment has resulted, among others, in a huge external debt, amounting to $\$ 2.2$ billion on June 30 , 1968. A major part of this debt was contracted on unfavorable terms and was earmarked for military undertakings with negative or law economic productivity. While the government successfully rescheduled external debts falling due both in 1967 and 1968, and is expected to be able to achieve the same in 1969, this action will increase the already heavy debt service payments falling due after 1970. Average debt repayment throughout the $1970^{\prime} \mathrm{s}$ is estimated to be in the order of $22-23$ per cent of foreign exchange earnings. ${ }^{39}$

The impact of foreign direct investment on the balance of payments cannot be easily assessed. Trying to measure the relative benefits from such investments as compared to those derived from foreign credits is even more complicated. The balance of payments effect of private direct investment includes the foreign exchange earnings or savings resulting from the project itself. This is frequently not the case in foreign loan projects because of the long gestation periods of infrastructural projects for which such aid is generally given.

In the case of balance of payments program aid, which in Indonesia is sold on the so-called Bonus Export market to general importers for a wide range of essential goods including certain consumer goods, debt-servicing will have to come from other foreign exchange creating sectors. On the other hand, the direct effect of foreign investment inflow on alleviating balance of payments problems arising out of trade deficits is quite limited, as the initial foreign exchange inflow is chiefly used to import such things as machinery, drilling equipment, etc. A larger inflow than necessary, which may be deliberately contracted by the investor who is at the same time the supplier

39. REPELITA, Vol. I, P. III-22. This assumes new loans to be predominantly contracted on D.A.C. terms of 20 years maturity, 7 years grace period and $3 \%$ interest. 
of equipment, will have an adverse effect on the future balance of payments because of excessive outflow to service such investment.

In the present Indonesian investment policy, no guidelines as yet exist to estimate the net foreign exchange gains or savings from a specific capital inflow in order to determine the eligibility of the project to qualify for exemptions under the law. Moreover, the law states that no restrictions will be placed on the remittance of profits. The only way to encourage the reinvestment of profits will therefore have to be through fiscal measures. In projects where the foreign exchange benefit to the country is not clear, such as in "import-intensive" importsubstitution projects (assembly plants or "packaging" industries), an unlimited transfer of profits will result in a continuous strain on the balance of payments.

Table 6 presents the summary of balance of payments projections for the five year plan period. It shows that private capital is expected to come in at an accelerating rate, reaching $\$ 171$ million dollars by $1973 / 74$, or three times the inflow expected in 1969-70. Judging from the present rate of approvals of applications for investment, the total of $\$ 571$ million expected over the five year period is probably not too excessive a target, although permits to invest, as indicated earlier, should not be confused with actual investments.

Private capital inflow estimates presumably incorporate expected changes in external reserves. They also include an expected back-flow of private "domestic" capital which had been kept abroad during previous unsettled times and of proceeds from technical smuggling originating from "overprice" proceeds, 40 as well as from outright smuggling.

As shown in Table 6 , the government will not solely rely on private capital investment but will still depend heavily on foreign aid throughout the plan period. For 1968 , commodity or program aid requested by Indonesia amounted to $\$ 250$ million, while project loans requested total $\$ 75$ million. Actual program aid received, including PL 480 aid, was $\$ 254$ million, while additional food aid of $\$ 58$ million was delivered. Thus total nonproject aid amounted to $\$ 304$ million. Taking account of the amount carried over from 1967 of $\$ 26$ million and an estimated carryover into 1969 of $\$ 32$ million, actual utilization of program aid for 1968 is about $\$ 298$ million, contributing substantially

40. Overprice proceeds is the foreign exchange revenue accruing to exporters resulting from the difference between prices actually obtained in foreign markets and the "checkprices" deliberately set below world prices on which export taxes and official foreign exchange earnings are calculated. This system has been in use for many years to provide added incentive to encourage exports. 
Summary of Balance of Payments Projections 1969/70 - 1973/74

(in millions U.S. \$)

\begin{tabular}{|c|c|c|c|c|c|}
\hline & $1969 / 70$ & $1970 / 71$ & $1971 / 72$ & $1972 / 73$ & $1973 / 74$ \\
\hline 2. Exports $\left(f . \circ \cdot b_{.}\right)^{a}$ & 672 & 775 & 784 & 827 & 924 \\
\hline 2. Imports $(f . \circ . b .)^{a}$ & -876 & $-1,058$ & $-1,194$ & $-1,310$ & $-1,438$ \\
\hline 3. Services ${ }^{a}$ & -197 & -237 & -281 & -320 & -362 \\
\hline Current Account Balance & -401 & -520 & -691 & -803 & -876 \\
\hline \multicolumn{6}{|l|}{ Capital Account $\mathrm{A}^{\mathrm{b}}$} \\
\hline 1. Debt repayment ${ }^{a}$ & -58 & -179 & -203 & -202 & -205 \\
\hline 2. Capital inflow required & 459 & 699 & 894 & $\underline{1,005}$ & 1,081 \\
\hline a) Government & 402 & 613 & 780 & 862 & 910 \\
\hline b) Private & 57 & 86 & 114 & 143 & 171 \\
\hline \multicolumn{6}{|l|}{ Capital Account $\mathrm{B}^{\mathrm{b}}$} \\
\hline 1. Debt repayment ${ }^{\mathrm{a}}$ & -58 & -- & -- & -- & -- \\
\hline 2. Capital inflow required & 459 & 520 & 691 & 803 & 876 \\
\hline a) Government & 402 & 434 & 577 & 660 & 705 \\
\hline b) Private & 57 & 86 & 114 & 143 & 171 \\
\hline
\end{tabular}

Source: REPELITA, Vol. I, Chapter III.

a. Exports include "net" oil exports, i.e., oil exports minus cost of production and other costs, and investment income accruing to foreign oil companies. It also excludes foreign exchange costs of domestic marketing and debt payments to expropriated Shell Company. The imports, services and debt repayment accounts are therefore net of oil payments.

b. Capital Account A assumes foreign debts falling due without rescheduling. Capital Account $B$ assumes such debts to be rescheduled fully. (See text for explanation) 
to the stability of rice and other prices throughout the year.

The contribution of foreign direct investment on export earnings will be more important than the inflow of the capital itself. As described earlier, the prospects for increasing ex-. port earnings from petroleum, forestry, fisheries and other relatively new exports such as copper, nickel and bauxite are very good and the annual compound rate of growth of exports of 6.6 per cent suggested by Table 6 may even prove to be on the low side. Of course, a continuing decline in rubber and tin prices in world markets would lower overall export rates of growth, except if offset by really spectacular rates of growth in new exports which benefit from expanding demand trends in world trade.

The above is reflected in the plan, as rates of growth projected for different categories of exports vary widely. During the plan period, category A exports, or traditional exports, including rubber, tin-in-concentrates, copra, palm-oil, coffee and tobacco leaves and manufactured tobacco, is expected to grow at an annual rate of only 3.4 per cent, reaching $\$ 503$ million by 1973/74. The rate of growth for category $B$ exports, on the other hand, which include all other exports except oil, is expected to be 14.9 per cent annually, while petroleum exports are expected to grow by 10.4 per cent annualiy.

Imports are expected to grow very rapidly also, but their composition is expected to change significantly. In 1969/70, food imports will take up 19.3 per cent of imports, raw materials and intermediate goods 31.5 per cent, capital goods 27.8 per cent and other consumer goods 21.3 per cent. The $1973 / 74$ proportions are estimated to be: food imports 4.6 per cent, raw materials 44.1 per cent, capital goods 38.7 per cent and other consumer goods 12.5 per cent.

The rapid growth of imports, estimated at an annual compounded average rate of 12.1 per cent will outpace the rate of growth of exports. This will result in a persistent current account deficit in the balance of payments. It should be noted that Indonesia's balance of payments between 1961 and 1966 also experienced a persistent deficit in the current account, but it is hoped that the balance of payments developments in the crucial years of the five year plan will be accompanied by an acceleration in the rate of economic growth which is the ultimate objective of development policy.

Foreign investment is expected to contribute substantially to the acceleration in the expected rate of growth. However, if sustained high rates of growth in the long run are envisaged, foreign investment should be directed more towards manufacturing, whether it is of the import-substituting or of the exportprocessing variety. In order to foster foreign investment in these sectors, specific incentives should be provided. Moreover, 
exchange regulations and administrative bureaucracy should be simplified, while corporation laws and tax rates should be changed to favor such fields of endeavor. In addition, the Technical Committee on Foreign Capital Investment should be given more power and should become a genuine Board of Investment empowered to approve investment applications in the field of manufacturing and services, without having to deal with the departments concerned. It is understandable that in mining and forestry, the departments concerned should have a hand in giving approval to particular foreign investors as this concerns the wealth of the country, but such procedures applied to manufacturing and services serve little purpose and are reminiscent of the past, when as many departments as possible were involved in imposing controls and restrictions on private enterprise. 